\title{
EFEK PENAMBAHAN L-KARNITIN PADA PAKAN TERHADAP LAJU PERTUMBUHAN BENIH LOBSTER AIR TAWAR (Cherax qudricarinatus)
}

\section{The addition of L-carnitine Effect On Growth Of Seeds Feeding Freshwater Lobster (Cherax quadricarinatus)}

Fandi Wahono ${ }^{1}$, Agustono ${ }^{2}$, dan Mirni Lamid ${ }^{3}$

${ }^{1}$ Program Studi Budidaya Perairan, Fakultas Perikanan dan Kelautan, Universitas Airlangga, Surabaya

${ }^{2}$ Departemen Manajemen Kesehatan Ikan dan Budidaya Perairan, Fakultas Perikanan dan Kelautan, Universitas Airlangga, Surabaya

${ }^{3}$ Fakultas Kedokteran Hewan, Universitas Airlangga, Surabaya

*okky-h-10@fpk.unair.ac.id

\begin{abstract}
Abstrak
Lobster Air Tawar (Cherax quadricarinatus) merupakan salah satu komoditas perikanan yang bernilai ekonomis tinggi, baik untuk lobster konsumsi ataupun lobster hias. Kebutuhan Lobster Air Tawar konsumsi semakin meningkat, namun produksinya masih sangat rendah sehingga harga di pasaran relatif tinggi. Pakan merupakan salah satu komponen budidaya yang sangat besar peranannya sebagai faktor penentu pertumbuhan maupun dari segi biaya produksi. Hasil penelitian menunjukkan bahwa udang putih yang diberi pakan dengan tambahan $500 \mathrm{ppm}$ L-karnitin menunjukkan pertumbuhan yang optimal. Adanya penelitian tentang L-karnitin yang mampu meningkatkan pertumbuhan udang putih maka diharapkan juga mampu meningkatkan pertumbuhan Lobster Air Tawar. Penelitian ini bertujuan untuk mengetahui pengaruh penambahan L-karnitin pada pakan terhadap pertumbuhan benih Lobster Air Tawar (Cherax quadricarinatus). Metode penelitian ini adalah eksperimen dengan Rancangan Acak Lengkap (RAL). Hasil penelitian ini menunjukkan bahwa pemberian dosis L-karnitin yang berbeda pada pakan buatan menghasilkan laju pertumbuhan harian dan efisiensi pakan yang berbeda nyata $(\mathrm{p}<0,05)$. Pertumbuhan benih Lobster Air Tawar (Cherax quadricarinatus) terbaik pada perlakuan D sebesar 0,72 gr/hari, dan efisiensi pakan terbaik pada perlakuan D sebesar 90,68\%.
\end{abstract}

Kata kunci : Laju Pertumbuhan, Efisiensi Pakan, Lobster Air Tawar, L-karnitin

Abstract

Freshwater Lobster (Cherax quadricarinatus) is one of the economically valuable fishery commodities tinggibaik to lobster lobster consumption or ornamental. Needs Fresh Water Lobster consumption is increasing, but production is still very low so that the market price is relatively high. Feed is one component of a very large role culture as determinants of growth and in terms of production costs. The results showed that white shrimp fed with $500 \mathrm{ppm}$ added L-carnitine showed optimal growth. There is research on L-carnitine were able to increase the growth of white shrimp is expected to increase the growth of Freshwater Lobster. This study aimed to investigate the effect of the addition of L-carnitine on feed on seed growth Lobater Freshwater (Cherax quadricarinatus). This research method is the experiment with completely randomized design (CRD). The results of this study indicate that administration of L-carnitine doses of different artificial feed produced daily growth rate and feed efficiency were significantly different $(p<0.05)$. Growth seeds Freshwater Lobster (Cherax quadricarinatus) best $\mathrm{D}$ in the treatment of $0.72 \mathrm{~g} /$ day, and the best feed efficiency in treatment $\mathrm{D}$ at $90.68 \%$.

Key word: Growth Rate, Feed Efficiency, L-carnitine, Freshwater Lobster

\section{PENDAHULUAN}

Lobster air tawar (Cherax quadricarinatus) merupakan salah satu komoditas perikanan yang bernilai ekonomis tinggi baik untuk lobster konsumsi ataupun lobster hias (Wiyanto dan Hartono, 2003). Permintaan lobster konsumsi untuk wilayah Bali diperkirakan mencapai 1-2 ton/tahun, untuk permintaan ekspor di negara Korea mencapai 6 ton/ tahun namun produksi nasional lobster air tawar hanya mencapai 3 ton/tahun (Trobos, 2010). Lobster air tawar dengan berat 80 gr merupakan ukuran konsumsi dengan permintaan pasar yang relatif tinggi tetapi jumlahnya masih sedikit. Hal

Diterima/submitted:21 November 2013

Disetujui/accepted:11 Desember 2013 
ini disebabkan karena waktu yang diperlukan untuk menghasilkan lobster ukuran konsumsi berkisar antara 7-10 bulan (Dermawan, 2004). Kebutuhan lobster air tawar konsumsi semakin meningkat, namun produksinya masih sangat rendah sehingga harga di pasaran relatif tinggi (Patasik, 2004).

Pakan merupakan salah satu komponen budidaya yang sangat besar peranannya sebagai faktor penentu pertumbuhan maupun dari segi biaya produksi (Affandi dan Tang, 2002). Lobster termasuk hewan omnivora sehingga lobster dapat diberi pakan berbagai jenis pakan hewani dan nabati, baik berupa pakan alami maupun pakan buatan (Iskandar, 2003).

Penambahan L-karnitin pada pakan mempunyai potensi yang positif untuk meningkatkan pertumbuhan dan katabolisme lemak (Chatzifotis dan Takeuchi, 1997). L-Karnitin berperan pada intermediary metabolisme yang diperlukan untuk mengoksidasi asam lemak rantai panjang di dalam mitokondria yang menghasilkan energi metabollik (Owen et al., 2001 dan Blanchard et al., 2002). Lkarnitin juga berperan dalam pengaturan rasio $\mathrm{Coa} / \mathrm{CoA}-\mathrm{SH}$ yang penting dalam katabolisme karbohidrat dan lemak (Chatzifotis et al., 1996 dan Vaz et al., 2002).

Hasil penelitian menunjukkan bahwa udang putih yang diberi pakan dengan tambahan 500 ppm L-karnitin menunjukkan pertumbuhan yang optimal (Jayaparkas dan Sambhu, 1996). Adanya penelitian tentang L-karnitin yang mampu meningkatkan pertumbuhan udang putih sehingga diharapkan juga dapat meningkatkan pertumbuhan lobster air tawar. Berdasarkan hal tersebut di atas maka perlu dilakukan penelitian untuk mengetahui pemberian feed additive (Lkarnitin) terhadap pertumbuhan benih dan efisiensi pakan pada lobster air tawar.

Penelitian ini bertujuan untuk mengetahui pengaruh penambahan 1karnitin pada pakan terhadap pertumbuhan benih lobster air tawar serta peningkatan efisensi pakan. Manfaat dari penelitian ini diharapkan dapat memberikan informasi untuk meningkatkan pertumbuhan dan produksi lobster air tawar, serta dapat digunakan untuk penyusunan formulasi pakan.

\section{METODOLOGI \\ Waktu dan Tempat}

Penelitian ini akan dilaksanakan di laboratorium pendidikan Fakultas Perikanan dan Kelautan Universitas Airlangga dan Fakultas Kedokteran Hewan Universitas Airlangga pada bulan JuniAgustus 2012.

\section{Materi Penelitian}

\section{Peralatan Penelitian}

Peralatan yang digunakan terdiri dari akuarium dengan ukuran $30 \times 20 \times 20$ $\mathrm{cm}$, selang, penggilingan, pengayakan, alat pencetak pellet, oven, $\mathrm{pH}$ meter, termometer, DO meter, aerator, timbangan analitik, rooster dan serokan.

\section{Bahan Penelitian}

Bahan yang digunakan berupa lobster air tawar 2-4 gr yang di dapatkan di sentra penjualan ikan hias Jemursari Surabaya. Pakan yang digunakan berupa pakan buatan yang terdiri dari tepung ikan,tepung udang,tepung kedelai dan tepung terigu. Adapun kandungan nutrisi dari campuran bahan pakan tersebut yang tertulis pada Tabel. 2 dan feed additive Lkarnitin murni merek weider dengan kandungan $500 \mathrm{mg}$.

\section{Metode Penelitian}

Penelitian ini menggunakan Rancangan Acak Lengkap (RAL), yang terdiri dari 6 perlakuan, masing-masing 3 ulangan. Penelitian ini menggunakan metode penelitian eksperimen yaitu hasil yang didapat menegaskan bagaimana hubungan antara variabel yang diselidiki dan berapa besar hubungan sebab akibat tersebut, dengan cara memberikan perlakuan-perlakuan tertentu pada

Diterima/submitted:21 November 2013 Disetujui/accepted: 11 Desember 2013 
beberapa kelompok eksperimental dan menyediakan kontrol untuk perbandingan (Anslem dan Juliet,2003).

\section{Prosedur Kerja}

Tahapan penelitian ini diawali dengan persiapan media penelitian. Media penelitian dibersihkan terlebih dahulu menggunakan air tawar kemudian di keringkan. Setelah itu diisi air serta di aerasi terlebih dahulu sebelum digunakan. Kemudian mempersiapkan bahan pakan dengan ditimbang terlebih dahulu sebelum digunakan. Setelah itu dilakukan pencampuran mulai dari bahan yg paling sedikit hingga bahan yang paling banyak agar homogen. Kemudian bahan d kukus selama 20menit. Kemudian adonan di cetak menggunakan mesin penggiling. Kemudian dikeringkan menggunakan oven dengan suhu $60^{\circ}$ C. Kemudian pellet siap untuk digunakan. Komposisi pakan antara perlakuan dihitung menggunakan metode trial. Kemudian Lobster air tawar yang baru datang di aklimatisasi terlebih dahulu dengan air media pemeliharaan. Setelah itu dibiarkan selama 2 hari dengan diberi pakan cacing tubifex. Setelah itu, udang dipindah di media penelitian dengan kepadatan 5 ekor per bak penelitian. Setelah udang masuk didalam bak penelitian, udang diberi pakan berupa pelet tenggelam. Pemberian pakan diberikan pada pagi dan sore hari. Pemberian pakan dilakuakan secara adsatiation. Banyak nya pakan yang diberikan dicatat untuk dijadikan dasar dalam menghitung nilai efisiensi pakan.

\section{HASIL DAN PEMBAHASAN \\ Hasil}

Hasil penelitian ini menunjukkan bahwa laju pertumbuhan rata-rata harian semakin meningkat dengan bertambahnya dosis L-karnitin yang diberikan. Laju pertumbuhan rata-rata harian tertinggi diperoleh pada perlakuan D dengan pemberian dosis L-karnitin sebesar 600 ppm sebesar $0.72 \mathrm{gr} /$ hari. Sedangakan laju pertumbuhan yang rendah diperoleh pada perlakuan A yang tidak berbeda nyata dengan perlakuan B dan F. Pada perlakuan D terlihat bahwa laju pertumbuhan tertinggi Lobster Air Tawar didapat dengan penambahan dosis L-karnitin dalam bahan pakan sebesar 600 ppm. Hal ini diduga terjadi karena adanya peran Lkarnitin dalam membantu proses metabolisme asam lemak rantai panjang. Asam lemak dan CoA bereaksi kemudian masuk ke dalam membran mitokondria. Asam lemak dan CoA tersebut bereaksi dengan karnitin kemudian masuk kedalam matrix mitokondria. Di dalam matrix mitokondria karnitin dilepas kembali menuju keluar matirx mitokondria untuk kemudian bereaski kembali dengan asam lemak dan CoA didalam membran mitokondria sedangkan Asam lemak dan CoA mengalami proses oksidasi asam lemak. Hal ini sesuai dengan pernyataan Chatzifotis and Takeuchi (1997) yang menyatakan bahwa fungsi L-karnitin adalah berperan membantu transfer asam lemak rantai panjang ke dalam mitokondria untuk dioksidasi (Chatzifotis and Takeuchi, 1997). Peningkatan oksidasi asam lemak akan meningkatkan jumlah energi non protein untuk kegiatan metabolisme tubuh. Dengan meningkatnya katabolisme lemak menyebabkan naiknya ketersediaan energi yang berasal dari non protein untuk metabolisme, sedangkan energi dari protein digunakan untuk proses anabolik (Chatzifotis et al. 1996).

Pada perlakuan $\mathrm{F}$ dengan dosis penambahan L-karnitin sebesar 800 ppm menunjukkan hasil pertumbuhan yang rendah. Hal ini terjadi karena penambahan dosis L-karnitin yang semakin tinggi tidak selalu memberikan respon pertumbuhan yang positif. Owen et. al. (2001) mengatakan bahwa adanya suplemen Lkarnitin dapat meningkatkan rasio $\mathrm{CoA} / \mathrm{CoA}-\mathrm{SH}$ mitokondria sehingga meningkatkan oksidasi asam lemak rantai panjang. Semakin tinggi dosis L-karnitin yang diberikan, proses oksidasi asam lemak rantai panjang semakin tinggi sehingga udang mengalami defisiensi asam

Diterima/submitted:21 November 2013 Disetujui/accepted:11 Desember 2013 
lemak rantai panjang. Asam lemak berperan penting dalam pemeliharaan membran sel, sehingga apabila tidak terpenuhi dapat mengganggu proses metabolisme sel. Hal ini akan menghambat sintesis protein tubuh yang berakibat pada penurunan pertumbuhan.

Hasil penelitian ini menunjukkan bahwa pemberian L-karnitin yang berbeda pada pakan terhadap efisiensi pakan Lobster Air Tawar menunjukkan tingkat efisiensi pakan yang berbeda sangat nyata. Efisiensi pakan tertinggi diperoleh pada perlakuan D sebesar 90,68\% yang berbeda sangat nyata dengan perlakuan A. Sedangkan efisiensi pakan yang rendah diperoleh pada perlakuan $\mathrm{A}$ yang tidak berbeda nyata dengan perlakuan E,C,B dan F.

Pada perlakuan D terlihat bahwa efisiensi pakan tertinggi Lobster Air Tawar sebesar 90,68\%. Meningkatnya efisiensi pakan pada perlakuan D disebabkan oleh meningkatnya konsumsi pakan dan jumlah nutrisi yang terserap kedalam tubuh lobster air tawar. Meningkatnya jumlah nutrisi yang terserap kedalam tubuh lobster air tawar diduga disebabkan oleh L-karnitin bekerja secara optimal pada perlakuan D. Seperti yang kita ketahui bahwa L-karnitin bekerja membantu meningkatkan metabolisme asam lemak rantai panjang, dengan meningkatnya metabolisme asam lemak rantai panjang ketersediaan energi non protein semakin tinggi dan energi dari protein digunakan secara optimal oleh lobster air tawar untuk pertumbuhan. Semakin tinggi laju pertumbuhan lobster air tawar maka efisiensi pakan pun semakin bagus. Hal ini sesuai dengan pendapat Djarijah (1995) yang mengatakan bahwa faktor yang menentukan tinggi rendahnya efisiensi pakan adalah macam sumber nutrisi dan jumlah dari tiap-tiap komponen sumber nutrisi dalam pakan tersebut.

Pada perlakuan $\mathrm{F}$ efisisensi pakan tidak berbeda nyata dengan perlakuan A. Hal ini disebabkan oleh tinggi nya Lkarnitin didalam bahan pakan tidak menjamin semakin tinggi efisiensi pakan lobster air tawar. Hal ini diduga terjadi karena semakin tinggi dosis L-karnitin yang diberikan makan L-karnitin terlalu banyak bereaksi dengan asam lemak dalam tubuh lobster air tawar sehingga lobster air tawar mengalami defisiensi asam lemak. Hal ini menyebabkan proses metabolisme didalam tubuh lobster air tawar terganggu. Hal ini sesuai dengan pendapat Hariati (1989) yang menyatakan bahwa kekurangan asam lemak esensial dapat ditunjukkan dengan gejala penurunan berat dan efisiensi pakan yang kecil.

\section{KESIMPULAN DAN SARAN Kesimpulan}

Dari hasil penelitian ini diperoleh simpulan bahwa pemberian pakan dengan dosis L-karnitin 600 ppm mampu meningkatkan laju pertumbuhan benih Lobster Air Tawar sebesar 0,72 gr/hari dan efisiensi pakan sebesar 90,68\%.

\section{Saran}

Pemberian dosis L-karnitin sebesar 600 ppm ke dalam pakan disarankan pada benih Lobster Air tawar.

\section{DAFTAR PUSTAKA}

Affandi, R. dan U.M. Tang. 2002. Fisiologi Hewan Air. Universitas Riau Press. Riau.

Anslem S dan C Juliet. 2003. Dasar-Dasar Penelitian Kuantitatif Tata Langkah dan Teknik-Teknik Teoritisasi Data. Pustaka Pelajar. Yogyakarta. 309 hal.

Chatzifotis, S., \& T. Takeuchi T. 1997. Effect of supplemental carnitine on body weight loss,proximate and lipid compositions and carnitine content of Red Sea Bream (Pagrus major)during starvation. Aquaculture 158:129-140.

Chatzifotis. S., T. Takeuchi, \& T. Seikai. 1996. The effect of carnitine supplementation on growth of red sea Bream (Pagrus major) 
fingerlings at two levels of dietary lysine. Aquculture 147:235-248.

Dermawan, R. 2004. Permintaan tak terbendung. Trubus. Jakarta. hal 122-123.

Djarijah. 1995. Pakan Ikan Alami. Kanisius. Yogyakarta.

Hariati, A. M. 1989. Makanan Ikan. UNIBRAW/LUW/Fisheris Product Universitas Brawijaya. Malang.

Iskandar, T. 2003. Budidaya Lobster Air Tawar. Agro Media Pustaka. Jakarta. 30-34 hal.

Jayaparkas, V., Sambhu, C. 1996. Growth Response Of White Prawn, Penaeus indicus, To Dietary Lcarnitine. Asian Fisheris Science, 9: 2009-219.

Owen KQ, Ji H, Maxwell CV, Nelseen JL, Goodband RD, Tokach MD, Tremblay GC, Koo SI. 2001. Dietary L-carnitine suppresesses mitochondrial branched-chain keto acid dehydrogenase activity and enhances protein accreation and carcass characteristic of swine. J. Amin. Sci., 79:3104-3112.

Patasik, S. 2004. Pembenihan Lobster Air Tawar Lokal Papua. Edisi 1. Penebar Swadaya. Depok. 34-50 hal.

Vaz, F.M., B. Melegh, J. Bene, D. Cuebas, D.A.Gace, A. Bootsama, P. Vreken, A.H.V. Gennip, L.L. Biebir, \& R.J.A. Wanders. 2002. Analysis of carnitine biosynthesis metabolities in urine by HPLCelectrospray tandem mass spectrometry. Clinical Chemistry 48(6):826-834.

Wiyanto, R. H. dan Hartono, R. 2003. Lobster Air Tawar Pembenihan dan Pembesaran. Penebar Swadaya. Depok. 30 hal. 